\title{
Psycholinguistic Meaning of the Concept of «Faith»
}

\section{Психолингвистическое значение концепта «вера»}

\author{
Tamara Khomulenko \\ Dr. in Psychology, \\ Professor
}

\author{
Тамара Хомуленко \\ доктор психологических наук, \\ професор
}

E-mail: tamarakhom108@gmail.com
orcid.org/0000-0003-3962-0795

Oleksiy Kuznetsov

Ph.D. in Psychology
Алексей Кузнецов

кандидат психологических наук

E-mail: o.kuznetsov@seznam.cz
orcid.org/0000-0002-1699-7859

H.S. Skovoroda Kharkiv National

Pedagogical University

29, Alchevsky Str., Kharkiv,

Ukraine, 61002
Харьковский национальный педагогический университет имени Г.С. Сковородь ул. Алчевских, 29, г. Харьков, Украина, 61002

Original manuscript received September 25, 2018

Revised manuscript accepted February 17, 2019

\begin{abstract}
The article presents the results of a free associative experiment aimed at studying the verbalized concept of "faith" in the ordinary linguistic consciousness. The sample consisted of 487 people, speakers both of Russian and Ukrainian languages (1567 years old) in an equal ratio of male and female. The article provides an analysis of the frequencies of the first reaction to the word-stimulus "faith" and the five reactions together, and the results of the clustering of high-frequency associations.
\end{abstract}


The psycholinguistic meaning of the concept of faith was considered by us as an ordered unity of all the semantic components of the lexeme "faith", which are really connected with this sound form in the consciousness of the speakers of the Russian and Ukrainian languages. The study showed that the concept of "faith" is expressed in the nuclear psycholinguistic meaning "hope». The results of the experiment suggest that the associative field of the concept "faith" is represented by theological (religious) and moral semes, reflected in the peripheral psycholinguistic meanings - "love», "religion", "God", "church" and many other meanings of the extreme periphery. It was shown that faith represents the "female name», which acts as a detotat of females, which also explains the high frequency of personalized reactions. The etymological analysis of the lexeme "faith" allowed us to correlate the primary meanings of this concept with its meanings in the content of the modern ordinary consciousness and to conclude that some of the original meanings of faith remained ("trust», "confidence», "oath", "verity», "religion», "deity»), and some of the meanings have been lost. In general, our results are confirmed in the works of both foreign and domestic scientists devoted to the analysis and description of the concept of "faith", which is characterized by several semantic levels, ambivalence, high-frequency associates of theological and moral semantics, the presence of metaphorical and emotive values.

Key words: faith, concept, psycholinguistic experiment, free associative experiment, religious discourse, linguistic consciousness.

\section{Введение}

Психолингвистические исследования религиозного дискурса в Украине, касающиеся отдельных концептов, приобретают все большую актуальность. Так, в современной психолингвистике по данным ассоциативного эксперимента были определены особенности вербальной репрезентации украинцами концепта «церковь» (Коструба, 2018) и «проповедь» (Чміль, 2017). Н.М. Савелюк определила психолингвистические универсалии понимания молитвы «Отче наш» (2017a), проанализировала ряд религиозных концептов (2017b). П.В. Мацкив изучил концептосферу Бог (Мацьків, 2006), определил семантическое пространство лексемы «вера» (Мацьків, 2016), Е. Климкив (Климків, 2012) на материале библейских текстов изучил фразеологическую реализацию концепта «вера». В исследовании Т. Мостовой прослеживается семантическая эволюция концепта «вера», основные направления развития и приоритетность отдельных аспектов его реализации, раскрывается последовательность становления его семантических признаков, 
определяются отдельные звенья семантемы, выпавшие и не фиксирующиеся в современном употреблении. О.В. Герасимович (2013) выполнен этимологический анализ лексемы вера в русском, украинском и белорусском языках, выделено общее и специфичное в понимании веры их носителями.

По мнению В.И. Карасик (Карасик, 2002: 221-229), ключевым концептом для религиозного дискурса выступает «вера». О.В. Гошовская (Гошовська, 2011) подчеркивает, что первичное значение слова не было связано с религиозной сферой, но с утверждением христианства «вера» обогатила свою структуру. Ю.А. Алексеева (Алєксєєва, 2014) подчеркивает более широкий объем понятия «вера» в сравнении с «доверием», «уверенностью» и «надеждой». Анализируя полученную К. Коломиец (Коломієць, 2014) многоуровневую структуру концепта «вера» в украинском языке, можно прийти к выводу, что первый ее уровень представлен «верой» в Абсолют, второй - «уверенностью», которая, по сути выступает верой в Себя, а третий - «доверием» как верой в Другого. К. Коломиец (Коломієць, 2014) также подчеркнуто субъект-объектный характер веры, поскольку вера выступает звеном между лицом (верующим человеком) и тем, во что (в кого) он верит. Тем не менее, в настоящее время в психолингвистике отсутствуют какие-либо достоверные результаты определения психолингвистического значения концепта «вера», полученные в результате психолингвистического эксперимента, чему и была посвящена данная работа.

Феномен веры также является предметом исследования в зарубежной психологии (Fowler, 1981, 1991) и религиозном дискурсе (Clyne \& Bouma, 1994; Francis, 2005; Haskell, Paradis \& Burgoyne, 2008). Анализируя библейские тексты О.Д. Иябод (Iyabode, 2012) указывает на связь религиозной веры (faith) с верой как убеждением (belief) и помощью (help). В. Смит (Smith, 1998) подчеркивает отличия между религиозной верой как способом реагирования личности или группы на трансцендентные ценности и силы, осознанные через формы кумулятивной традиции (faith) и верой как убеждением, приверженностью определенным идеям (belief). М. Грабовская (Grabowska, 2013) рассматривает концепт «вера в Бога» на двух уровнях: на личностном, связанном с индивидуальными потребностями и 
смыслами человека и представленням ассоциатами «радость», «надежда», «доверие», «утешение» и «правда», «помощь», «личный опыт», и на социальном, где вера отождествляется с религией и представлена ассоциатами «убеждение», «правило», «духовность», «ценности», «сверхъестественные силы», «доказательство», «религия», «поддержка».

Дж. Фоулер (Fowler, 1981) рассматривает формирование религиозной веры в онтогенезе и предлагает семь стадий: первичная недифференцированная вера или вера-доверие к близким людям (от рождения до двух лет); интуитивно-проективная вера как приобщение к религиозному опыту взрослых (от трех до семи лет); мифическая буквальная вера, характеризующаяся антропоморфными представлениями о Боге (школьный возраст); синтетически-общепринятая вера (начиная с подросткового возраста), характеризующаяся интериоризацией религиозных представлений и убеждений; индивидуально-рефлексивная вера (20-30 лет) как стадия тоски и борьбы, на которой личность несет личную ответственность за свои убеждения и чувства, способна размышлять над собственными убеждениями; конъюнктивная вера (кризис среднего возраста), при которой личность признает парадокс и трансцендентность, связанные с реальностью и символами унаследованных систем, разрешает конфликты предыдущих стадий через осознание и понимание многомерной, взаимозависимой «истины», которую нельзя объяснить каким-либо конкретным утверждением; универсальная вера как «просветление», на которой личность будет относиться к другим с состраданием согласно универсальным принципам любви и справедливости. Рассмотрение стадий развития веры и новообразований религиозного развития личности приближает нас к пониманию концепта веры, связывая его с доверием, любовью, сочувствием, просветлением.

«Вера», по мнению Степанова, - концепт уникальный» (Степанов, 1997: 62) и рассматривается автором как «внутреннее состояние каждого отдельного человека, которому невозможно дать исчерпывающее описание, поскольку в его процессе мы доходим до границы научного знания. Тем не менее, как считает автор, рассмотрение основных составляющих значения концепта веры возможно. Трудности в изучении, определении и истолковывании абстрактных понятий, таких как «вера», связаны с «многомерностью 
семантического наполнения и социокультурной, и дискурсной вариативностью, обусловливающим «размытость», нечеткость их семантических границ» (Воркачев, 2007: 129).

Психолингвистическое значение слова - это упорядоченное единство всех семантических компонентов, которые реально связаны с данной звуковой оболочкой в сознании носителей языка. Это тот объем семантических компонентов, который актуализирует изолированно взятое слово в сознании носителей языка, в единстве всех образующих его семантических признаков - более и менее ярких, ядерных и периферийных (Стернин \& Саломатина, 2011). И.Г. Овчинникова под психолингвистическим значением понимает интерпретацию экспериментальных данных, позволяющую установить смыслы, связанные со словом в языковом сознании» (Овчинникова, 2009: 261). Психолингвистическое значение достаточно конкретно и определенно - это реально представленное в языковом сознании носителей языка значение, выявляемое и описываемое по результатам психолингвистических экспериментов.

В психологии «значение» понимается как системное качество, приобретаемое смыслом слова или высказывания (или компонентом этого смысла) в условиях единства смыслообразующего контекста (Леонтьев, 2003). Под значением понимается сущность предмета, соотнесенная с некоторым знаком; под смыслом - интерпретация этого значения некоторым множеством реципиентов на основе данных коллективного и/или личного опыта» (Сорокин, 1985: 59). В психолингвистике операционализация смысла в структуре индивидуального или коллективного сознания производится посредством изучения концептов. Термин «концепт» наиболее точно определяется Ю. Степановым как «содержание понятия, синонимичный «смыслу слова», а термин «значение» представляет собой «объем понятия, предмет или предметы, по отношению к которым это слово правильно применено, в соответствии с нормами данного языка» (Степанов, 1997: 43). Выделенные в результате описания концепта аспекты концептуализации позволяют определить отдельные значения интересующей исследователя единицы, характеризующие разные явления, но объединяемые при этом в сознании человека единым концептом (Стернин \& Рудакова, 2011: 74). 
Цель настоящей работы состоит в том, чтобы на основе прикладного психолингвистического исследования описать психолингвистические значения вербализированного концепта «вера».

\section{Методы исследования}

Основным методом проведенного исследования был психолингвистический эксперимент, главным этапом которого выступил свободный ассоциативный эксперимент (САЭ) со словомстимулом «вера». Дополнительными методами были опрос (с целью уточнения результатов САЭ), анкетирование (для уточнения характеристик выборки). В качестве математико-статистических методов анализа результатов исследования применялись частотный и кластерный анализ, которые позволили выявить тенденции в распределении ассоциаций.

САЭ со словом-стимулом «вера» проводился в письменной форме. Согласно инструкции испытуемые указали пол, возраст, образование/специальность, семейное положение и написали первые пять слов, которые пришли им в голову, с которыми у них ассоциировалось слово «вера».

Общее число испытуемых, которые приняли участие в эксперименте, составило 487 (15-67 лет), в равном соотношении мужчин и женщин. Из них по критерию места проживания: 74,4\% жителей города Харькова и Харьковской области, 10,2\% города Славянск, Донецкой области, 15,4\% жителей города Винница. В результате анкетирования было выяснено, что все респонденты относят себя к носителям как русского, так и украинского языков.

\section{Результаты исследования}

По результатам частотного анализа САЭ на стимул «ВЕРА» были построены ассоциативные поля по пяти реакциям и по первой реакции. На слово-стимул «вера» испытуемые дали 2170 реакций (обработка результатов САЭ по пяти реакциям), включая 58 словосочетаний или законченных предложений, реакций с частотой больше 1 - 166, единичных - 371, отказов 0, не знают значение слова -0 . 
Обработка результатов САЭ на стимул «вера» по первой реакции дала соответственно 487 ассоциации, включая 14 словосочетаний, реакций с частотой больше $1-45$, единичных -89 , отказов - 0, не знают значение слова -0 . Наиболее высокочастотные ассоциации показаны в таблице 1.

Таблица 1. Частота ассоциаций на слово-стимул «вера» по пяти реакциям САЭ

\begin{tabular}{lcc}
\hline \multicolumn{1}{c}{ Ассоциаты } & Абс. & Частота, \% \\
\hline надежда [надежда 251, надежда на что-то 1, сподівання 1] & 253 & 11,6 \\
любовь [любовь 133, кохання 1, ..в любовь 2] & 136 & 6,3 \\
религия & 111 & 5,1 \\
Бог [Бог 95, в Бога 5] & 100 & 4,6 \\
имя [имя 71, женское имя 2] & 73 & 3,4 \\
церковь & 70 & 3,2 \\
доверие [доверие 46, доверчивость 2, доверять кому-то 1] & 49 & 2,3 \\
уверенность & 34 & 1,6 \\
жизнь & 30 & 1,4 \\
сила [сила 21, сильная 2] & 23 & 1 \\
\hline
\end{tabular}

Ассоциациям, встречающимся в ассоциативном поле, включающим пять реакций на стимул «вера», были присвоены ранги. Рассмотрим высокочастнотные реакции, соответствующие первым 20 рангам: «надежда», словосочетание «надежда на что-то», «надія», «сподівання» 253 (11,6\%) - ранг 1. При полевой стратификации результатов экспериментальных исследований значения и концепта И.А. Стернин и А.В. Рудакова (2011) предлагают относить ассоциации с частотой более $10 \%$ к ядру поля. В случае концепта «вера» ядерной ассоциацией следует считать слово «надежда». В зону поля ближней периферии (ассоциации с частотой 4-10\%) входят: «любовь», «кохання», словосочетание «в любовь» $136(6,3 \%)$ - ранг 2, «религия» $111(5,1 \%)$ - ранг 3, «Бог» $100(4,6 \%)$ - ранг 4. В зону дальней периферии (ассоциации с частотой 2-3\%) входят: «имя», «женское имя» 73 (3,4\%) - ранг 5, «церковь» 70 (3,2\%) - ранг 6, «доверие», словосочетание «доверять кому-то», «доверчивость» 49 (2,3\%) - ранг 7. К крайней периферии (ассоциации с частотой менее $2 \%$ ) входят все остальные ассоциации, среди которых наибольшую частоту имеют: «уверенность» 
34 (1,6\%) - ранг 8, «жсизь» 30 (1,4\%) - ранг 9, «сила», «сильная» $23(1 \%)$ - ранг 10, а также равночастотные реакиии «искренность», «щирість» 20 (0,9\%) и «молитва» и «молиться» $20(0,9 \%)$ - ранг 11,5, «свет» и «світло» 19 (0,9\%) - ранг 13, словосочетание «в себя» $17(0,8 \%)$, «душа» 17 (0,8\%), «счастье», «щастя» 17 (0,8\%), «человек», «людина» $17(0,8 \%)$, «будущее» и «в будущеее» $17(0,8 \%)$ - ранг 16, «поддержка» $16(0,7 \%)$ - ранг 19, «добро» $15(0,6 \%)$, «мечта» и «мечтыл» 15 (0,6\%), «честность», «чесність» $15(0,6 \%)$, «чувство» $15(0,6 \%)$ - ранг 21,5.

Как видим, в ассоциативном поле по пяти реакциям встречаются лексемы, преимущественно, моральной семантики «надежда» $u$ «любовь», а также «добро», «честность» и религиозной семантики «религия», «Бог», «иерковь», «молитва», а также «Библия» 11 (0,5\%). Кроме того, высока доля ассоциирования слова «вера» с именем собственным - женским именем Вера. Среди реакций, отражающих значение имени также встречаются такие имена собственные, как «Брежнева» 2, «Глаголева» 1 , «Полозкова» 1 .

Частыми рекциями на слово-стимул «вера» являются однокоренные слова «доверие» 49 (2,3\%) и «уверенность» 34 (1,6\%), а также реакции с меньшей частотой - «верность» 11, «верить» 3, «верование» 2, «верочсповедание» 2, «самоуверенность» 2, «веруюшие» 2, «верный» 2, «проверка» 1. К группе специфических ассоциаций на стимул «вера» следует отнести слова «жизнь» и «сила».

Затем была проведена частичная семная интерпретация результатов частотного анализа САЭ на стимул «ВЕРА» по первой реакции. По результатам анализа данных, полученных после частичной семной интерпретации, изменилась последовательность некоторых высокочастотных ассоциатов зон ядра и ближней периферии, состав и характер ассоциаций с меньшей частотой, находящихся в периферии, также изменился (см. табл. 2).

Лексема «надежда» по первой реакции так же, как и по всем реакциям сразу, занимает первый ранг, имея наибольшую частоту (25,6\%). Если по результатам анализа всех реакций второй ранг был у лексемы «любовь», то по первой реакции второй ранг получила лексема «религия» 41 (8,4\%). «Любовь» 40 и «Бог» 40 занимают, соответственно, ранг 3,5. В зону ближней периферии входит «Имя» 
24 (4,9\%) - 5 ранг. Такие ассоциации, как «церковь» 13 (2,6\%) 6 ранг, «сила» и «сильная» $9(1,8 \%)-7$ ранг, составляют зону дальней периферии. Ассоциации «в себя» 7 (1,4\%) - 8 ранг, «человек» $6(1,2 \%)$ - 9 ранг, «жизнь» и «духовность» по $5(1 \%)-$ 10,5 ранги, «желание», «жива», «крест», «поддержка», «убеждения», «уверенность», «чудо» имеют одинаковую частоту - $4(0,8 \%)$, и занимают, соответственно, 15 ранг, и являются высокочастотными реакциями зоны крайней периферии.

Таблица 2. Частота ассоциаций на слово-стимул «вера» по первой реакции САЭ

\begin{tabular}{lcc}
\multicolumn{1}{c}{ Ассоциаты } & Абс. & Частота, \% \\
\hline Надежда [надежда 125, надежда на что-то 1, сподівання 1] & 127 & 25,6 \\
религия & 41 & 8,4 \\
любовь [любовь 37, кохання 1, ...в любовь 2] & 40 & 8,2 \\
Бог [Бог 36, в Бога 4] & 40 & 8,2 \\
имя [имя 22, женское имя 2] & 24 & 4,9 \\
церковь & 13 & 2,6 \\
сила [сила 8, сильная 1] & 9 & 1,8 \\
...в себя [...в себя 6, ...в самого себя 1] & 7 & 1,4 \\
человек [человек 5, людина 1] & 6 & 1,2 \\
духовность & 5 & 1 \\
жизнь & 5 & 1 \\
\hline
\end{tabular}

Сравнительный анализ ассоциативных полей по пяти и по первой реакции позволил сделать вывод, что состав и характер реакций не имеет существенных отличий по лексемам с наивысшими рангами - «надежда», «любовь», «религия», «Бог», «имя», «церковь» (см. рис. 1).

Следующим заданием было определение таксономических групп высокочастотных ассоциаций ядра и периферии, по которым можно судить об их семантической близости. С этой целью из 487 респондентов были отобраны 283, у которых из 5 реакций хотя бы две являются высокочастотными, т.е. с наивысшими рангами - «надежда», «любовь», «религия», «Бог», «имя», «иерковь», «уверенность», «доверие», «сила» и «жизнь». По каждому испытуемому в таблицу заносились баллы за реакции, вербализированные в определенной последовательности. 
Ассоциациям, выступившим первой реакцией присваивалось пять баллов, второй - четыре, третьей - три, четвертой - два и пятой, соответственно, один балл. Если те или иные ассоциаты не выступили реакциями респондента, они оценивались в ноль баллов. Полученные данные подлежали кластеризации.

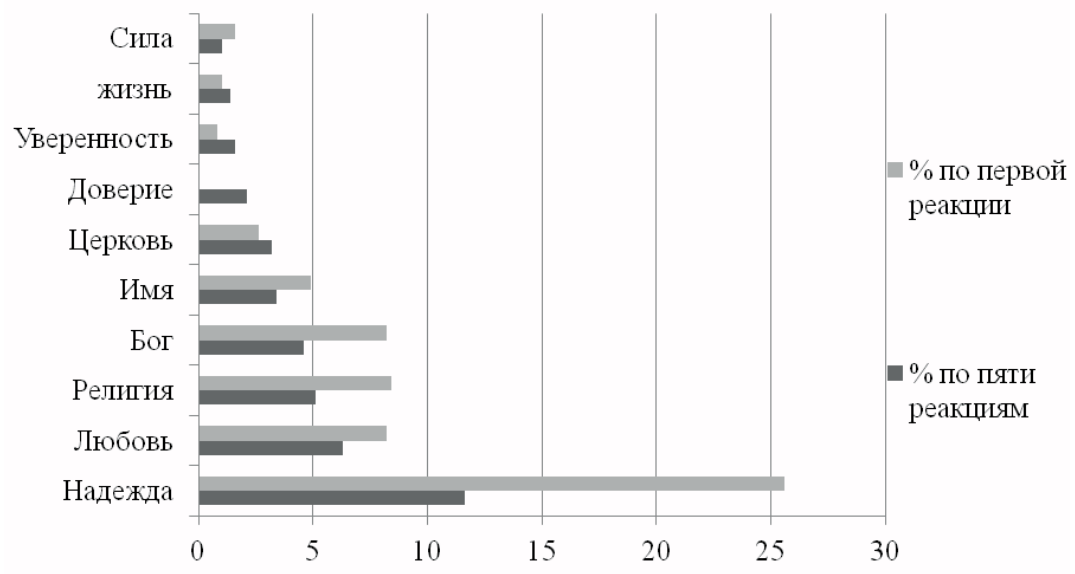

Рис. 1. Результаты сравнительного анализа ассоциативных полей по первой и по пяти реакцииям стимула «вера»

Кластерный анализ методом Варда показал, что вербализированный концепт «вера» репрезентируется двумя семантическими группами ассоциаций (рис. 1): 1) «любовь надежда» и 2) «религия - жизнь», причем второй кластер представлен несколькими подкластерами: 1) «Бог - церковь», наиболее близкой ассоциацией к которому является «религия»; 2) «уверенность - сила - жизнь» с ближайшей ассоциацией «доверие». Слово «имя» является относительно самостоятельным, так как в одинаковой степени часто сочетается с «доверием», «уверенностью», «силой», «жизнью».

На следующем этапе исследования были осмыслены периферийные и единичные реакции по совокупности всех реакций испытуемых (2170). Единичные реакции, отражающие индивидуальные смыслы испытуемых, обусловленные содержанием их индивидуального опыта, следующие: актриса, верные друзья, бабушка, богатство, богиня, борьба, брат, бред, великий предел, вечность, взаимность, взаимопонимание, влияние, влюбленность, 
воздушность, война, воля, время, выживание, выход, всемогущество, гибель, Глаголева, гордость, гос.экзамен, день, движение вперед, дверь, дорога, железо, жестокость, забота, закономерность, закрыто, заменитель, защита, зеленая трава, игра, Индия, интеллектуалка, кома, комфорт, коричневый, краткость, логика, любопытство, мама, мачеха, маяк, манипуляции, молодость, море, мягко, находка, настырность, опека, опора, отдача, ответственность, подвиг, подруга, поле, Полозкова, Порошенко, прогресс, просьба, работа, равноправие, рамки, результат, родственники, самооченка, свекровь, сегодня, сказка, сложности, снег, соответствие, спор, суичид, творчество, тихо, толчок, трава, трудности, упасть в воду, устойчивость, упорство, учеба, учитель, уют, хлеб, холод, ияветок лотоса, шаг, шар, я, и прочие.

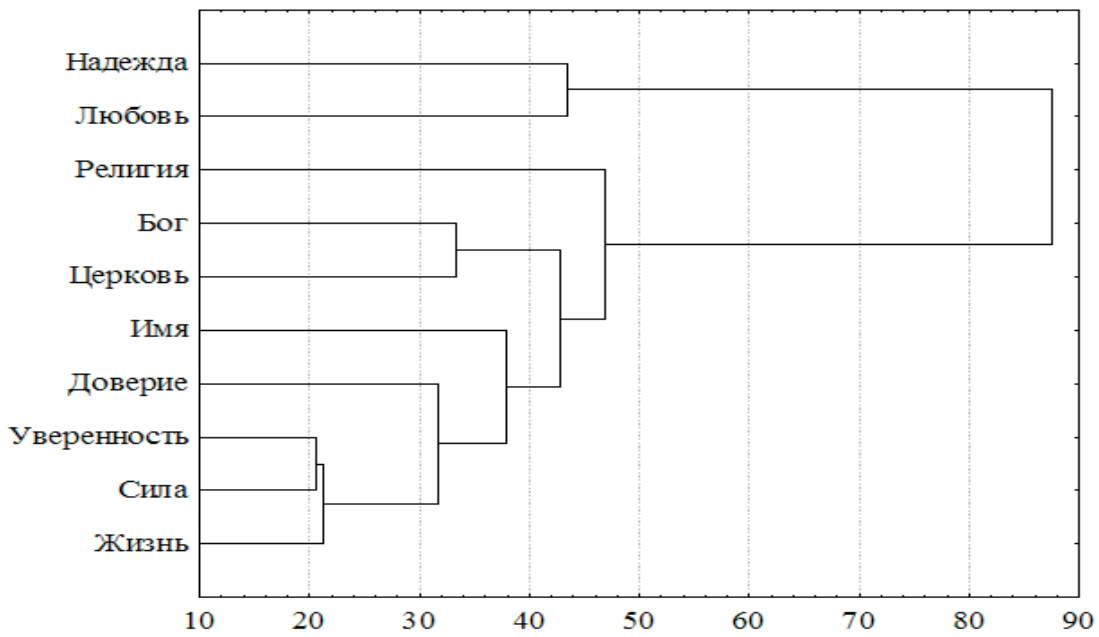

Рис. 2. Таксономия ассоџиаџий концеепта «вера»

Значительную группу периферийных и единичных реакций составили лексемы, относящиеся к ассоциативному полю религиозной тематики: православие 8, храм 7, духовность 6, дух 5, икона 5, поп 5, священник 5, Иисус 4, небо 4, Будда 3, ислам 3, монах 3, християнство 3, божество 2, буддизм 2, исповедь 2, праведность 2, Рим 2, свечи 2, святость 2, служба 2. К единичным реакциям данного ассоциативного поля относятся: слова и словосочетания, являющиеся ассоциациями семантики в рамках духовно-религиозной, теологической тематики: аминь, 
ангел, батюшка, благославление, богиня, Ватикан, верба, голубь, душа, идоль, излечение, инь и ян, исцеление, исповедь, католищизм, крешуение, Кришна, луч, медитация, невидимое, неведомое, нить, озарение, паломничество, праведность, праздник, прощчение, рай, Рождество, Святое Писание, святость, секта, символ верь, спасение, терпимость, толпа, учение, хор, Христос, церковная служба, фанатизм.

Большую группу слов и словосочетаний составляют являющиеся ассоциациями семантики в рамках широкой бытийной (философско-онтологической, метафизической, экзистенциальной и психологической) тематики: безграничность, безликость, безнадежность, безопасность, безысходность, бесконечная, беспокойство, благие помысльл, благодарность, бытие, взгляд, видение мира, внутреннее, возвыпиенность, воля, все уже решено за нас, высокое, высшия, гармония, грядущуее, данность, дар, знания, единство, идеология, идеи, культура, мировоззрение, мировосприятие, мироздание, мудрец, мудрость, неосознанное, опора, основа, помощьь, понимание, преданность, предчувствие знаний, психология, равноправие, равность, смысл жсизни, справедливость, символ, система внутренних убеждений, суждение, факт, человечность, честность, чистота, чуенное качество, эскапизм, эфемерная, ясность.

Следует также выделить группу единичных реакций, описывающих положительные эмоциональные состояния: вдохновение, везение, возвышенное чувство, все получится, гордость, зашчиценность, ожидание, оптимизм, отчаяние, ощуциение, радость, счастье, удовлетворение, удача, успех, успокоение, чувство, шанс, эмоциональность и другие.

Подсчет негативных реакций позволяет сделать вывод, что в целом отношение респондентов к слову-стимулу «вера» положительное. Всего немногим более, чем у 1,5\% респондентов слово «вера» вызывает негативное отношение или скепсис (34 реакции): ложь 7, обман 3, иллюзия 2, наивность 2, иллюзия 2, и наивный 1, бред 1, вранье 1, глупость 1, заблужсдение 1, идиотизм 1, клевета 1, напрасная 1, нежелание разобраться в чем-то 1, незнание 1, несущуествуюшее явление 1, обман 1, плацебо 1, разочарование 1, самовнушение 1, самообман 1, слепая 1, слепота 1, утопия 1. Оппозитные по смыслу реакции встречаются 
чаще: правда 10, истина 9, поддержка 4, жива 4, чудо 4, доброта 3, интуиция 3, легкость 3, непоколебимая 1, опора 1, стабильность 1, стойкость 1, умирает последней 1 и другие.

Итогом проведенного исследования было описание психолингвистических значений концепта «вера».

Вера (487 исп.).

Результаты семантической интерпретации результатов эксперимента. Слово ВЕРА ассоциируется с:

1. НАДЕЖДОЙ 253 (надежда 253 [надежный 12, надеяться]);

2. и ЛЮБОВЬЮ 136 [верой в Любовь]);

3. Входит в семантическое пространство РЕЛИГИИ (111) и связана с ЦЕРКОВЬЮ (70), то есть имеет теологическое значение (более 110 семантически близких к «религии» и «церкви» слов и словосочетаний);

4. Отождествляется с ИМЕНЕМ (73) или с носителями имени (18);

5. По природе амбивалентно, поскольку может быть как источником ИСТИНЫ (19), так и ЛЖИ (34);

6. Является категорией морали, так как ассоциируется с добром (15), честностью (15), миром (11), добротой (10), помощью (10), верностью (9), духовностью (6), преданностью (6), справедливостью (5), уважением (4), верностью (3);

7. Характеризуется искренностью (3), крепкостю (2), непоколебимостью (2), силой (2), безграничностью (1), бесконечностью (1), надежностью (1), неприкосновенностью (1), несломленностью (1), эфемерностью (1); не имеет конияа (1), может быть умной (2), напрасной (1) или настоящей (1), неумирающей (1), строгой (1).

\section{Обсуждение}

Анализ описанных выше психолингвистических значений вербализированного концепта «вера» свидетельствуют о его многокомпонентном, многоуровневом и амбивалентном характере. Представленное исследование подтверждает данные, полученные в работе К. Коломиец (Коломієць, 2014), где приводится анализ 
многоуровневой структуры концепта «вера»в украинском языке, в которой первый уровень представлен «верой в сверхъестественное, Высший Разум, признание существования Бога», следующий пласт содержит «уверенность в чем-либо, или уверенность в положительных качествах кого-либо», а третий (периферия) «доверять как отношение кому-либо, основанное на его честности, правоте, искренности, харизме». Действительно, большинство полученных ассоциаций к стимулу «вера» имеют теологическую семантику, хотя и не входят в ядерную зону значений концепта «веры», а выделенные К. Коломиец (Коломієць, 2014) значения «уверенности» и «доверия» входят в периферию изученного нами концепта.

В исследовании (Коломієць, 2014), проведенном на украиноязычной выборке, также было показано, что к значениям «веры» относятся: Бог, наївність, забобони, довіра, розчарування, довіряти, покладатися, упевнитися, завзяття, правильність, істина, релігія, почуття, поневіряння, зневіра, недовіра, вірогідність, вірність, чесність, віровизнання, віросповідання, щирість. В нашем исследовании показано, что некоторые из указанных выше значений имеют высокие частоты, например, религия 111, Бог 100, доверие 46. Многие из указанных автором значений в нашем исследование попали в зону дальней и крайней периферии: чувство 15, честность 15, верность 9, истина 9, наивность и наивный 3, вероисповедание 2, искренность 2, разочарование 1, доверять 1. Однако, однокоренные слова, показанные К. Коломиец, по результатам нашего психолингвистического эксперимента не являются элементами ассоциативного поля веры.

Как показало наше исследование, ассоциативное поле концепта «вера» очень широко, некоторые периферийные и единичные реакции интерпретируются достаточно сложно и неоднозначно. Этимологический анализ слова «вера» позволяет дать более точную и полную интерпретацию тех или иных ассоциаций.

О.М. Ямницкая (Ямницька, 2016) реконструировала первичные формы лексемы «вера»: 1) вера как моральная категория, 2) честность в ведении политических дел; 3) христианское учение; 4) обещание; 5) сосредоточенность на внутренней вере. Первой форме соответствуют полученные в нашем исследование ассоциации в рамках моральной семантики (надежда 253, любовь 133, 
добро 15, честность 15), второй форме - честность 15, а третьей християнство 3, католицизм 1, православне 8, храм 7, икона 5, non 5, священние 5, Иисус 4, монах 3 и проч. Такая первичная форма «веры» как «обещание» не представлена напрямую, а выражена косвенно через ассоциации верность 3, клятва 1, предательство 1, преданность 1, долг 1, обман 1, обязанность 1. Пятая первичная форма «веры» - «сосредоточенность на внутренней вере» представлена ассоциациями по результатам САЭ внутреннее 1, система внутренних убеждений 1.

Этимологический анализ слова «вера», произведенный П.А. Флоренским, а также проведенный в наших предыдущих работах (Kuznetsov, 2017; Кузнецов, 2017a, 2017b; Хомуленко, Кузнецов \& Фоменко, 2018) позволяет сопоставить некоторые труднообъяснимые ассоциации с первичными значениями веры в древних языках. Например, еврейское слово «вера» связано с «истиной», которая в нашем исследовании представлена 9 реакциями. В Бхагават-Гите вера понимается как принятие в качестве истины всего сказаного Богом (Прабгупада, 2015: 482). На санскрите вера («сраддсха») означает «положить сердце на Бога» и связано с «уважением», «преданностью», «желанием» и «потребностью», что отражается в наших результатах: реакций сердие - 3, Бог 100, уважение - 4, преданность - 6, желание - 4, исполнение желаний - 1, заветное желание - 1, нужда - 1. Фонетически близкое слово раддха означает «успех», «процветание», «поток любви», «приносить удовольствие», «служение», что представлено в реакциях успех 14 и в успех 1, служба 1, поклонение 1. Л. Голуб, А. Другова, П. Голуб (2013: 213) указывают на то, что сраддха это «вера, преданность и искренность, то есть уверенность в себе и доверие к другим» (преданность 1, уверенность 34, вера в себя 17, доверие 46). Авторы указывают, что основаниями для такой веры есть авторитет, прецедент, врожденное знание, прямое интуитивное постижение, содержание собственного сознания в измененном состоянии (знание 3, интуиция 1). Истинная непоколебимая вера порождает энергию (virya), которая способствует достижению цели (целеустремленность 2, цель 9).

По опредлению С. Сидорова, вера - это «опора», «упование» на Три Драгоценности (Будду, Дхарму, Сангху) 
(Сидоров, 2005: 96-105). В нашем исследовании было показано возникновение реакции опора 1 на слово-стимул «вера».

Китайский иероглиф «синь» означает сразу и веру, и истину, и сознание одновременно (Еремеев, 2005). Смысл этого иероглифа дословно означает «слова человека», «слова из сердца». В нашем исследовании получены следующие реакции: истина 9, слова 2, сердие 3. Синь используется как искренность, убежденность, мужество, благонадежность, правильность, истинность, верность, стойкость (по результатам САЭ: искренность 20, убежденность 4, верность 9).

Греческий глагол «верить» соотносится со значением «слушаться», и в нашем эксперименте были зафиксированы такие две соответствующие реакции, как повиновение 1 и послушание 1 . В русском и латинском языках вера отождествляется с доверием (доверие 46). Латинская вера «многолика»: verax - «говорящий правду», «тот, что знает истину», «истинный», vere - «истинно, правильно, верно», verum - «правда, истина, справедливость, правильность, veritas - «истина, «прямота», «искренность», «правдивость», «действительность», «правила», «нормы» (Дворецкий, 1996: 812-814). Очевидна близость веры с латинским verbum (слово), verna (раб, рабыня) придают ей характер ответственности и в то же время покровительства, защиты, надежды и ожидания. Также можно отметить связь со словом vivere (жизнь), в котором vi - сила, a vere - истинная, правильная, верная. Представленный ряд определений веры в латинском языке сопоставим с нашими результатами САЭ: правда 10, истина 9, искренность 20, защита 1, защчищенность 1 .

Дефиниционный анализ веры О.В. Герасимович (2013) указывают на то, что в древнерусском языке вера определяется, как «истина, правда; то чему можно верить», «верование (поклонение инстинам, догмам; идолам божествам»; «вероисповедание и религия», «вера в Бога, религиозное чувство», «доверие к кому-либо или чему-либо: а) поверить, оказать доверие; б) уверовать в Бога, принять веру», «обещание, заверение», «обычай», «основные догматы христианского вероучения», «текст символа веры», «христианская вера», «честность, добросовестность». По результатам нашего САЭ можно достоверно утверждать, что в современном обыденном языковом сознании некоторые значения, 
свойственные древнерусскому языку, были утрачены, например, «обещание», «обычай», «заверение», «уверовать», «вероучение», но большинство все же сохранилось и относятся к периферии истина 9, правда 10, божество 1, верование 2, символ 1, символ веры 1.

Элементами семантической структуры лексемы «вера» в русском языке, по данным О.В. Герасимович (2013), являются: «благочестие, религиозное рвение», «вероисповедание, религия», «верование, поклонение», «доверие», «желание, охота, намерение», «мнение», «обычай, традиция», «поверье, примета, передаваемая из поколения в поколение», «понятие, умение», «примета», «присяга, клятва», «проверка, установление правильности чего-то», «религиозное учение, вероисповедание», «религиозные представления, верования», «религиозный обряд, богослужение», «то, чему можно верить; вероятность, возможность», «убежденность, уверенность». Из выделенной группы лексем по результатам нашего САЭ вера представлена такими ассоциациями: религия 111, уверенность 34, убежденность 4, верование 2, вероисповедание 2, возможность 1, клятва 1.

Первым определением веры в словаре В. Даля приводится следующее: «уверенность, убеждение, твердое сознание, понятие о чем-либо (Даль, 1955: 73). В нашем исследовании уверенность имеет частоту $34(1,6 \%)$, убеждение - 14 (0,6\%), осознание - 2 (менее 0,01\%). У С.И. Ожегова (1990) вера в первую очередь понимается как: 1. убежденность, глубокая уверенность в ком-чемнибудь, и приводятся примеры - «вера в победу», «вера в людей». Субъект-объектный характер веры отражен в некоторых полученных нами реакциях САЭ: в себя 17, в лучшее 3, в любовь 3, в Бога 1, в будущее 1, в кого-то 1, в победу 1, в успех 1, в человека 1, во что-то хорошее 1.

Противоречивое отношение к вере, ее амбивалентность отражается не только с ее соотнесенностью с ложью и истиной, но в полярности оценок, имплицитно заложенных в полученных нами ассоциациях - положительных (радость 2, свет 2, спокойствие 2, ясность 2, благополучие 1, вдохновение 1, легкость 1 , непоколебимая 1, сильная 1, стабильность 1, стойкость 1 , счастье 1, тепло 1, удача 1, удовлетворение 1, ценное качество 1, 
чистота 1) и отрицательных (внушение 2, глупость 1, вранье 1, манипуляция 1, обязанность 1, самонадеянность 1, слепая 1) и т. п.

У $0,8 \%$ респондентов вербализация «веры» осуществляется с помощью персонификации: бабушка 8, мама 3, женщина 2, мачеха 1, Брежнева 1, Глаголева 1, Полозкова 1, девушка 1. В данном случае, вера приобретает значение имени.

Высока доля метафорической составляющей в реакциях на слово «вера»: Бог 100, молитва и молиться 20, крест 10, небо 4, сердие 3. Полученные реакции в целом соответствуют результатам исследования стимула «вера» с помощью классической методики «Пиктограммы», проведенного Н.М. Савелюк (2017b), где графически были олучены категории символов, которые опосредуют понимание концепта «вера», а именно: небесные символы, Бог, сердце.

Теологические ассоциаты и в нашем исследовании и работах других ученых, посвященных анализу концепта «вера», представлены ближней (религия 111, Бог 100), дальней (церковь 70) и крайней (молитва и молиться 20, Библия 11, крест 10, православне 8, храм 7, икона 5, поп 5, священние 5, Иисус 4, християнство 3, монах 3 верование 2, католищизм 1) периферией. Это говорит о том, что понимание религиозной сути концепта веры сохраняется.

В целом семантическое наполнение ядра слова «вера» представлено другим концептом - «надежда». По данным анализа русского и украинского ассоциативных словарей, проведенного О.В. Герасимович (2013), существует тесная ассоциативная связь понятий «вера» и «надежда»: так, первой ассоциацией и мужчин, и женщин на стимул «вера» является «надежда» и «надія» соответственно в русском и украинском языках.

\section{Выводы}

Результаты психолингвистического эксперимента показали, что вербализированный концепт «вера» в обыденном языковом сознании выражается в ядерном психолингвистическом значении «надежда».

Ассоциативное поле концепта «вера» представлено теологическими (религиозными), морально-нравственными семами, отраженными в периферийных психолингвистических значениях - 
«любовь», «религия», «Бог», «церковь» и множестве иных значений крайней периферии.

Поскольку в большинстве славянских языков слово «вера» выступает именем собственным, т.е. имеет значение «женское имя» и является денотатом лиц женского пола, то по результатам САЭ вера характеризуется высокой частотой персонифицированных реакций.

Этимологический анализ лексемы «вера» позволил соотнести первичные значения этого концепта с его значениями в содержании современного обыденного сознания и сделать вывод о том, что часть исконных значений веры сохранилась («доверие», «уверенность», «клятва», истина», «правда», «религия», «божество»), а часть значений была утрачена.

В целом полученные нами результаты находят свое подтверждение в работах как зарубежных, так и отечественных ученых, посвященных анализу и описанию концепта «вера», который характеризуется несколькими семантическими уровнями, амбивалентностью, высокочастными ассоциатами теологической и морально-нравственной семантики, наличием метафорических и эмотивных значений.

Перспективу дальнейших исследований видим в описании психолингвистических значений других концептов религиозного дискурса - души, Бога, религии и соотнесении их с ассоциативным полем концепта «вера».

\section{Литература}

Алєксєєва Ю.А. Психологічний аналіз семантичного простору концепту «віра». Проблеми сучасної психології: Зб. наук. прачь КПНУ ім. Івана Огієнка, Інституту психології ім. Г.С. Костюка НАПН Украӥни. 2014. Вип. 26. C. $40-54$.

Воркачев С.Г. Любовь как лингвокультурный концепт. Москва: Гнозис, 2007. $284 \mathrm{c}$.

Герасимович О.В. Восточнославянская семантическая аксиология (вера, надежда, любовь). Минск: Беларуская навука, 2013. 245 с.

Голуб Л.Ю., Другова О.Ю., Голуб П.Ю. Популярный словарь по буддизму и близким к нему учениям. Москва: Хроникер, 2003. 336 с.

Гошовська О.В. Семантичний простір концепту віра. Науковий часопис Національного педагогічного університету імені М.П. Драгоманова. 2011. Вип. 7. С. 391-396.

Даль В. Толковый словарь живого великорусского языка. Москва, 1955. T. $1.699 \mathrm{c}$. 
Дворецкий И.Х. Латинско-русский словарь. 4-е изд. Москва: Русский язык, 1996. 1096 c.

Еремеев В.Е. Символы и числа «Книги перемен». Москва: Ладомир, 2005. 600 с.

Карасик В.И. Языковой круг: личность, концепты, дискурс. Волгоград: Перемена, 2002. 477 c.

Климків С.М. Фразеологічна реалізація концепту «віра» в біблійних текстах. Наукові записки Національного університету «Острозька академія». 2012. Вип. 24. С. $125-128$.

Коломієць К. Концепт віри в українській мові [Електронний ресурс]. 2014. Режим доступу: http://ukrconf.fl.kpi.ua

Коструба Н. Вербальна репрезентація концепту «церква» (за даними асоціативного експерименту). Психолінгвістика. 2018. Вип. 23(1). С. 160-174. https://doi. org/10.5281/zenodo.1211185

Кузнецов О.I. Психологічний аналіз феномену віри у науковому пізнанні. Психологія і особистість. 2017а. Вип. 1(11). С. 289-297.

Кузнецов О.І. Религия в семантическом пространстве личности. Вісник ХНПУ ім. Г.С. Сковороди. Психологія. 2017b. Вип. 55. С. 58-67.

Леонтьев Д.А. Психология смысла: природа, строение и динамика смысловой реальности. Москва: Смысл, 2003. 488 с.

Мацьків П. Семантичний обшир лексеми віра: словниково-діахронний та фразеологічний аспекти. Проблеми гуманітарних наук. 2016. Вип. 38. C. 266-273.

Мацьків П.В. Концептосфера БОГ в українському мовному просторі. Дрогобич: Коло, 2006. 323 с.

Овчинникова И.Г. Диалог субкультур (концепты деньги и бизнес в сознании молодых россиян). Я $и$ другой в пространстве текста / Под ред. В.А. Салимовского. Пермь-Любляна, 2009. Вып. 2. С. 256-280.

Ожегов С.И. Словарь русского языка. Москва: Русский язык, 1990. 921 с.

Прабгупада С.Б. Бгагават-Iіта як вона $\epsilon$. Харків: Бхактіведанта бук траст, 2015. $760 \mathrm{c}$.

Савелюк Н.М. Психологічні особливості метафоричного розуміння базових релігійних концептів суб'єктами з різними рівнями релігійної активності. Психологічний часопис. 2017b. Вип. 4(8). С. 111-133.

Савелюк Н.М. Психолінгвістичні універсалії розуміння молитви «Отче наш» (дискурсивний підхід). East European Journal of Psycholinguistics. 2017a. Вип. 4(1). С. 175-187. doi: 10.5281/zenodo.831702

Сидоров С.А. Буддизм: история, каноны, культура. Москва: Астрель, 2005.

Сорокин Ю.А. Психолингвистические аспекты изучения текста. Москва: Наука, 1985. 168 c.

Степанов Ю.С. Константы: Словарь русской культуры: опыт исследования. Москва, 1997. С. 16-17.

Стернин И.А., Рудакова А.В. Психолингвистическое значение и его описание. Теоретические проблемы. LAP Lambert Academic Publishing» Saarbrücken, 2011. 192 c.

Стернин И.А., Саломатина М.С. Семантический анализ слова в контексте. Воронеж: «Истоки», 2011. 150 с.

Хомуленко Т.Б., Кузнецов О.І., Фоменко К.І. Молитва як предмет мовленнєвої діяльності та іiі комунікативний намір. Психолінгвістика. 2018. Вип. 23(1). C. 309-326. https://doi.org/10.5281/zenodo.1211565 
Чміль Н. Вербальна репрезентація концепту «проповідь» (за даними асоціативного експерименту). East European Journal of Psycholinguistics. 2017. Вип. 4(1). C. 30-39. doi: $10.5281 /$ zenodo. 824410

Ямницька О.М. Семантико-етимологічний аналіз концепту віра (на матеріалі англійської, української та французької мов). Науковий вісник Херсонського державного університету. 2016. Вип. 4. С. 118-122.

Clyne, M., \& Bouma, G.D. (1994). Talking about One's Life and Faith: A Pilot Project on Language and Religion. Text, 14(2), 167-184. https://doi.org/10.1515/ text.1.1994.14.2.167

Fowler, J.W. (1991). Stages in faith consciousness. New Directions for Child and Adolescent Development, 52, 27-45. https://doi.org/10.1002/cd.23219915204

Fowler, J.W. (1995). Stages of Faith: The Psychology of Human Development and the Quest for Meaning. San Francisco: Haper \& Row.

Francis, L.J. (2005). Faith and Psychology: Personality, Religion and the Individual. London: Darton, Longman and Todd.

Grabowska, M. (2013). Profiling the concept of Faith in God in the context of Construal Level Theory of Psychological Distance. Rocznik Kognitywistyczny, 6, 11-22.

Haskell, D.M., Paradis, K., \& Burgoyne, S. (2008). Defending the faith: Reaction to The DaVinci Code, The Jesus Papers, The Gospel of Judas and other pop culture discourses in Easter Sunday sermons. Review of Religious Research, 50(2), 139-156.

Iyabode, O.D. (2012). Faith as the Pivot for the Miraculous: A Discourse Analysis of a Biblical Text. Scriptura, 109, 28-35.

Kuznetsov, O. (2017). Religiousness: Components, Types and Coping Strategies. Science and education, 11, 70-75. https://doi.org/10.24195/2414-4665-2017-11-9

Smith, W.S. (1998). Faith and belief: The difference between them. Oxford: Oneworld.

\section{References}

Alekseeva, Y.A. (2014). Psykholohichnyy analiz semantychnoho prostoru kontseptu «vira» [Psychological analysis of the semantic space of the concept of «faith»]. Problemy suchasnoyi psykholohiyi - Problems of modern psychology, 26, 40-54 [in Ukrainian].

Vorkachev, S.G. (2007). Lyubov kak lingvokulturnyy kontsept [Love as a linguocultural concept]. Moscow: Gnosis [in Russian].

Gerasimovich, O.V. (2013). Vostochnoslavyanskaya semanticheskaya aksiologiya (vera, nadezhda, lyubov) [East Slavic semantic axiology (faith, hope, love)]. Minsk: Belarusian Nauka [in Russian].

Holub, L.Yu., Druhova, O.Yu., \& Holub, P.Yu. (2003). Populyarnyy slovar po buddyzmu y blyzkym $k$ nemu uchenyyam [A popular dictionary on Buddhism and related teachings]. Moscow: Khronyker [in Russian].

Goshovska, O.V. (2011). Semantychnyy prostir kontseptu vira [The semantic space of the concept of faith]. Naukovyy chasopys Natsionalnoho pedahohichnoho universytetu imeni M.P. Drahomanova - Scientific journal of the National Pedagogical University named after M.P. Drahomanov, 7, 391-396 [in Ukrainian].

Dal, V. (1955). Tolkovyy slovar zhivogo velikorusskogo yazyka [Explanatory Dictionary of the Living Great Russian Language]. (Vols. 1). Moscow. 
Dvoretskyy, I.Kh. (1996). Latynsko-russkyy slovar [Latin-Russian Dictionary] (4nd ed.). Moscow: Russkiy yazyk [in Russian].

Eremeev, V.E. (2005). Symvoly y chysla «Knyhy peremen» [Symbols and numbers of the "Book of Changes»]. Moscow: Ladomyr [in Russian].

Karasyk, V.Y. (2002). Yazykovoy kruh: lychnost, kontsepty, dyskurs [Language circle: personality, concepts, discourse]. Volhohrad: Peremena [in Russian].

Klymkiv, Ye.M. (2012). Frazeolohichna realizatsiya kontseptu «vira» v bibliynykh tekstakh [Phraseological realization of the concept of «faith» in biblical texts]. Naukovi zapysky Natsionanoho universytetu "Ostrozka akademiya» - Scientific notes of National University of Ostroh Academy, 24, 125-128 [in Ukrainian].

Kolomiyets, K. (2014). Kontsept viry v ukrayinskiy movi [Concept of Faith in the Ukrainian Language]. Retrieved from http://ukrconf.fl.kpi.ua [in Ukrainian].

Kostruba, N. (2018). Verbalna reprezentatsiya kontseptu «tserkva» (za danymy asotsiatyvnoho eksperymentu) [Verbal representation of the concept «church» (according to the associative experiment)]. Psykholinhvistyka - Psycholinguistics, 23(1), 160-174. https://doi.org/10.5281/zenodo.1211185 [in Ukrainian].

Kuznetsov, O.I. (2017a). Psykholohichnyy analiz fenomenu viry u naukovomu piznanni [Psychological analysis of the phenomenon of faith in scientific knowledge]. Psykholohiya i osobystist - Psychology and personality, 1(11), 289297 [in Ukrainian].

Kuznetsov, O.I. (2017b). Relyhyya v semantycheskom prostranstve lychnosty [Religion in the semantic space of the person.]. Visnyk KHNPU im. H.S. Skovorody H.S. Skovoroda KhNPU Herald, 55, 58-67 [in Russian].

Leontyev, D.A. (2003). Psykholohyya smysla: pryroda, stroenye y dynamyka smyslovoy realnosty [Psychology of meaning: nature, structure and dynamics of the semantic reality]. Moscow: Smysl [in Russian].

Matskiv, P. (2016). Semantychnyy obshyr leksemy vira: slovnykovo-diakhronnyy ta frazeolohichnyy aspekty [Semantic enormous verbal lexis: vocabulary-diachronic and phraseological aspects.]. Problemy humanitarnykh nauk - Problems of the humanities, 38, 266-273 [in Ukrainian].

Matskiv, P.V. (2006). Kontseptosfera BOH v ukrayinskomu movnomu prostori [Conceptosphere of GOD in the Ukrainian language space]. Drohobych: Kolo [in Ukrainian].

Ovchinnikova, I.G. (2009). Dialog subkultur (kontsepty dengi i biznes v soznanii molodykh rossiyan) [Subcultures dialogue (concepts of money and business in the minds of young Russians)]. V.A. Salimov (Ed.), Ya $i$ drugoy v prostranstve teksta - I and the other in the text space (Vols. 2), (pp. 256-280). PermLjubljana [in Russian].

Ozhehov, S.Y. (1990). Slovar russkoho yazyka [Dictionary of the Russian language]. Moscow: Russkiy yazyk [in Russian].

Prabhupada, S.B. (2015). Bhagavat-Gita yak vona ye [Bgaavat-Gita as she is]. Kharkiv: Bkhaktivedanta buk trast [in Ukrainian].

Savelyuk, N.M. (2017b). Psykholohichni osoblyvosti metaforychnoho rozuminnya bazovykh relihiynykh kontseptiv subyektamy $\mathrm{z}$ riznymy rivnyamy relihiynoyi aktyvnosti [Psychological features of metaphorical understanding of basic religious concepts by subjects with different levels of religious activity.]. Psykholohichnyy chasopys - Psychological Journal, 4(8), 111-133 [in Ukrainian].

Savelyuk, N.M. (2017a). Psykholinhvistychni universaliyi rozuminnya molytvy «Otche nash» (dyskursyvnyy pidkhid) [Psycholinguistic universals Understanding 
the prayer «Our Father» (discursive approach)]. East European Journal of Psycholinguistics, 4(1), 175-187. doi: 10.5281/zenodo.831702 [in Ukrainian].

Sydorov, S.A. (2005). Buddyzm: ystoryya, kanony, kultura [Buddhism: history, canons, culture]. Moscow: Astrel [in Russian].

Sorokin, Yu.A. (1985). Psikholingvisticheskiye aspekty izucheniya teksta [Psycholinguistic aspects of the study of the text]. Moscow: Nauka [in Russian].

Stepanov, Yu.S. (1997). Konstanty: Slovar russkoy kultury: opyt yssledovanyya [Constants: Dictionary of Russian culture: experience of research]. Moscow [in Russian].

Sternyn, Y.A., \& Rudakova, A.V. (2011). Psykholynhvystycheskoe znachenye y eho opysanye. Teoretycheskye problemy [Psycholinguistic meaning and its description. Theoretical problems]. LAP Lambert Academic Publishing: Saarbrücken [in Russian].

Sternyn, Y.A., \& Salomatyna, M.S. (2011). Semantycheskyy analyz slova v kontekste [Semantic analysis of the word in the context]. Voronezh: "Ystoky» [in Russian].

Khomulenko, T.B., Kuznetsov, O.I., \& Fomenko, K.I. (2018). Molytva yak predmet movlennyevoyi diyalnosti ta yiyi komunikatyvnyy namir [Prayer as a subject of speech activity and its communicative intention]. Psykholinhvistyka Psycholinguistics, 23(1), 309-326. https://doi.org/10.5281/zenodo.1211565 [in Ukrainian].

Chmil, N. (2017). Verbalna reprezentatsiya kontseptu «propovid» (za danymy asotsiatyvnoho eksperymentu) [Verbal Representation of the Concept «Sermon» (Based on the Association Test)]. East European Journal of Psycholinguistics, 4(1), 30-39. doi: 10.5281/zenodo.824410 [in Ukrainian].

Yamnytska, O.M. (2016). Semantyko-etymolohichnyy analiz kontseptu vira (na materiali anhliyskoyi, ukrayinskoyi ta frantsuzkoyi mov) [Semantic-etymological analysis of the concept of faith (on the material of English, Ukrainian and French).]. Naukovyy visnyk Khersonskoho derzhavnoho universytetu - Scientific Herald of Kherson State University, 4, 118-122 [in Ukrainian].

Clyne, M., \& Bouma, G.D. (1994). Talking about One's Life and Faith: A Pilot Project on Language and Religion. Text, 14(2), 167-184. https://doi.org/10.1515/ text.1.1994.14.2.167

Fowler, J.W. (1991). Stages in faith consciousness. New Directions for Child and Adolescent Development, 52, 27-45. https://doi.org/10.1002/cd.23219915204

Fowler, J.W. (1995). Stages of Faith: The Psychology of Human Development and the Quest for Meaning. San Francisco: Haper \& Row.

Francis, L.J. (2005). Faith and Psychology: Personality, Religion and the Individual. London: Darton, Longman and Todd.

Grabowska, M. (2013). Profiling the concept of Faith in God in the context of Construal Level Theory of Psychological Distance. Rocznik Kognitywistyczny, 6, 11-22.

Haskell, D.M., Paradis, K., \& Burgoyne, S. (2008). Defending the faith: Reaction to The DaVinci Code, The Jesus Papers, The Gospel of Judas and other pop culture discourses in Easter Sunday sermons. Review of Religious Research, 50(2), 139-156.

Iyabode, O.D. (2012). Faith as the Pivot for the Miraculous: A Discourse Analysis of a Biblical Text. Scriptura, 109, 28-35.

Kuznetsov, O. (2017). Religiousness: Components, Types and Coping Strategies. Science and education, 11, 70-75. https://doi.org/10.24195/2414-4665-2017-11-9

Smith, W.S. (1998). Faith and belief: The difference between them. Oxford: Oneworld. 


\section{АННОТАЦИЯ}

В cтатье представлены результаты свободного ассоциативного эксперимента, направленного на изучение вербализированного концепта "вера» в обыденном языковом сознании. Выборку составили 487 человек, носителей русского и украинского языков (15-67 лет) в равном соотношении мужского и женского пола. В статье приводится анализ частот первой реакции на словостимул "вера» и пяти реакций вместе, приведены результаты кластеризации высокочастотных ассоциаций. Психолингвистическое значение концепта «веры» рассматривалось нами как упорядоченное единство всех семантических компонентов лексемы "вера", реально связанных с данной звуковой оболочкой в сознании носителей русского и украинского языка. В исследовании показано, что концепт "вера» выражается в ядерном психолингвистическом значении «надежда». Результаты эксперимента позволяют утверждать, что ассоциативное поле концепта "вера" представлено теологическими (религиозными), морально-нравственными семами, отраженными в периферийных психолингвистических значениях - "любовь», "религия", "Бог», "церковь» и множестве иных значений крайней периферии. Было показано, что репрезентантами лексемы вера является "женское имя", которое выступает денотатом лиц женского пола, что также объясняет высокую частоту персонифицированных реакций. Этимологический анализ лексемы "вера» позволил соотнести первичные значения этого концепта с его значениями в содержании современного обыденного сознания и сделать вывод о том, что часть исконных значений веры сохранилась ("доверие», "уверенность», "клятва», истина», «правда», "религия», "божество»), а часть значений была утрачена. В целом полученные нами результаты находят свое подтверждение в работах как зарубежных, так и отечественных ученых, посвященных анализу и описанию концепта "вера», который характеризуется несколькими семантическими уровнями, амбивалентностью, высокочастными ассоциатами теологической и морально-нравственной семантики, наличием метафорических и эмотивных значений.

Ключевые слова: вера, концепт, психолингвистический эксперимент, свободный ассоциативный эксперимент, религиозный дискурс, языковое сознание.

\section{Хомуленко Тамара, Кузнецов Олексій. Психолінгвістичне значення концепту «віра»}

\section{АНОТАЦІЯ}

У статті представлені результати вільного асоціативного експерименту, спрямованого на вивчення вербалізованого концепту «віра» в повсякденній мовній свідомості. Вибірку склали 487 осіб, носіїв російської та української мов (15-67 років) в рівному співвідношенні чоловічої і жіночої cmami. у cmammi наводиться аналіз частот першої реакції на слово-стимул «віра» $і$ п'яти реакцій разом, наведені результати кластеризації високочастотних асочіацій. 
Психолінгвістичне значення концепту «віри» розглядалося нами як впорядкована єдність всіх семантичних компонентів лексеми "віра», реально пов'язаних з даною звуковою оболонкою в свідомості носіїв російської та української мови. У дослідженні показано, що концепт "віра» виражається в ядерному психолінгвістичному значенні “надія». Результати експерименту дозволяють стверджувати, що асоціативне поле концепту «віра» представлено теологічними (релігійними), морально-етичними семами, відбитими в периферійних психолінгвістичних значеннях - «любов», "релігія», "Бог», «церква» і безлічі інших значень крайньої периферії. Було показано, що репрезентантами лексеми "віра» $\epsilon$ "жіноче ім'я», яке виступає денотатом осіб жіночої статі, що також пояснює високу частоту персонірікованих реакцій. Етимологічний аналіз лексеми "віра» дозволив співвіднести первинні значення цього концепту з його значеннями в змісті сучасної буденної свідомості і зробити висновок про те, що частина споконвічних значень віри збереглася ("довіра», "впевненість", «клятва», істина», "правда», "релігія», "божество»), а частина значень була втрачена. У цілому отримані нами результати знаходять своє підтвердження в роботах як зарубіжних, так і вітчизняних вчених, присвячених аналізу та опису концепту «віра», який характеризується кількома семантичними рівнями, амбівалентністю, високочастотними асочіатами теологічної і моральноетичної семантики, наявністю метафоричних і емотивних значень.

Ключові слова: віра, концепт, психолінгвістичний експеримент, вільний асоціативний експеримент, релігійний дискурс, мовна свідомість. 